\title{
ОСНОВЫ КОНСТИТУЦИОННОГО СТАТУСА БРИТАНСКИХ ВИРГИНСКИХ ОСТРОВОВ КАК ЗАМОРСКОЙ ТЕРРИТОРИИ ВЕЛИКОБРИТАНИИ
}

\begin{abstract}
Аннотация. Предметом исследования являются нормативно-правовое содержание положений Конституции Виргинских островов 2007 года в части регламентации статуса публичных органов власти, должностных лиц. Изучены порядок формирования, состав, компетенция, ответственность публичных органов власти Виргинских островов.Также предмет исследования образует правовая природа политико-территориальных отношений Великобритании и ее заморских территорий. Отдельно рассматривается специфика материализации политико-территориальных отношений в плоскости конституционного статуса Виргинских островов. Проанализированы проблемные вопросы нормативно-правового обеспечения организации и взаимодействия в рамках существующей в современных условиях модели политико-территориального взаимодействия.Объектом является общественные отношения, возникающие в рамках конституционных предписаний, определяющих правовое положений публичных органов власти Виргинских островов. Основополагающим методом, использованным при написании настоящей статьи, является сравнительно-правовой. Результаты его применения позволили выявить различия и сходства, проблемные аспекты конституционного статуса Виргинских островов как заморской территории Великобритании. В российской конституционно-правовой науки предлагаемая статья является первой, в которой комплексно рассматриваются вопросы конституционного статуса Виргинских островов как заморской территории Великобритании. Сформулирован вывод о том, на Виргинских островах создана министериалистская система правления, при которой решающую роль в формировании и реализации конституционного курса играет Кабинет.Аргументируется позиция о том, что отношения между Великобританией и Виргинскими островами, именуемые в Белой книге заморских территорий как "партнерство», целесообразно квалифицировать как унитарные с элементами федеративных.Обосновывается необходимость конституционного закрепления порядка разграничения компетенции между публичными органами власти Великобритании и Виргинских островов с определением ответственности за исполнение задач и функций в конкретных срерах деятельности.Предлагается рассмотреть возможность обеспечения представительства Кабинета Виргинских островов в Правительстве Великобритании путем включения в его состав соответствующих министров. Также предлагается конституционно установить порядок представления Палатой Собрания в Парламент Великобритании информации о своем мнении по законопроектам, касающимся всего Королевства, а также предусмотреть направление Парламентом Великобритании проектов правовых актов, затрагивающих интересы Содружества, в адрес заморских территорий.Указывается на целесообразность введения процедуры проведения предварительных консультаций при обсуждении вопросов о назначении соответствующих кандидатур на должность Губер-
\end{abstract} натора Виргинских островов. Сфрормулирован вывод о том, что предварительное обсуждение с местными властями кандидатур Губернаторов целесообразно на всех заморских территориях.

Ключевые слова: британский монарх, заморские территории, Виргинские острова, Конституция, Губернатор, Кабинет, Палата Собрания, партнерство, Министр иностранных дел, виргинеи

Abstract. The research subject is the normative and legal contents of the provisions of the 2007 Virgin Islands Constitution in relation to the regulation of the status of public authorities and officials. The author studies the procedure of formation, the composition and competence of the public authorities of the Virgin Islands. The author also focuses on the legal nature of political and territorial relations of Britain with its overseas territories. The article studies the specificity of political and territorial relations materialization with regard to the constitutional status of the Virgin Islands. The author analyzes the problem issues of normative and legal provision of organization and interaction within the current model of political and territorial interaction. The research object is social relations within the constitutional provisions defining the legal status of public authorities of the Virgin Islands. The basic research method is comparative-legal. The results of the research help detect differences, similarities and problem aspects of the constitutional status of the Virgin Islands as a British overseas territory.This study is the first study of this issue in Russian constitutional legal science. It considers the problems of the constitutional status of the Virgin Islands as a British overseas territory. The author concludes that in the Virgin Islands there exists a ministerialist system in which the leading role in the formation and implementation of the constitutional course belongs to the Cabinet. This position is substantiated by the fact that the relations between Britain and the Virgin Islands, called in the White Paper 
on the Overseas Territories a "partnership", should be qualified as unitary with the elements of federative.The author substantiates the need for the constitutional consolidation of the procedure of competence division between the public authorities of Britain and the Virgin Islands by the distribution of authorities in particular spheres. The author suggests considering the possibility of ensuring the representation of the Virgin Islands Cabinet in the British Government by including the corresponding ministers. The author also suggests establishing a constitutional procedure of the House of Assembly informing the British Government about its position on the draft laws, related to the Kingdom in general, and the British Government sending the draft laws, affecting the interests of the Commonwealth, to the overseas territories. The author notes the reasonability to introduce the procedure of preliminary consultations in discussing the issues of appointing the candidates to the post of the Virgin Islands Governor. The author concludes that the preliminary discussion of Governor candidates with local authorities is appropriate in all overseas territories.

Key words: partnership, the House of Assembly, the Cabinet, the Governor, the Constitution, the Virgin Islands, the Overseas Territories, the British monarch, Secretary of State for Foreign and Commonwealth Af, Virgin Islander.

\section{1. Общая конституционная характеристика Британских Виргинских островов}

Виргинские острова представляют собой архипелаг в Карибском море.

Часть островов, среди которых наиболее крупными являются Сент-Томас, Сент-Джонс и Санта-Крус, находятся в западной части Карибского бассейна, имеют статус неинкорпорированной организованной территории США и именуются Американскими Виргинскими островами [1]. Данные острова были приобретены США в 1917 году у Дании.

Британские Виргинские острова (Виргинские острова - далее) являются заморской территорией Великобритании, расположены в северо-восточной части Карибского бассейна, состоят из 36 островов, из которых обитаемы только 13. Площадь архипелага составляет 153 кв. км, население - 27000 человек (по состоянию на 2005 год).

Виргинские острова были открыты Христофором Колумбом в 1493 году во время второго путешествия в Америку. Испанский мореплаватель назвал острова «Санта Урсула и 11000 виргинцев». Первое постоянное европейское поселение было организовано Голландией в 1648 году на острове Тортола. В 1672 году Великобритания захватила Тортолу, а в 1680 году аннексировала Анегаду и Верджин Горду.

Острова стали колонией Великобритании в 1762 году. С 1871 года по 1956 год эта часть архипелага входила в состав английской колонии Подветренные острова. Функции представительства британской Короны на Виргинских островах осуществлял Администратор. В 1960 году Британским Виргинским островам был предоставлен статус отдельной колонии, а в 1967 году острова приобрели автономию. С этого периода на Виргинских островах активно развивается туризм и рынок финансовых услуг. В текущий период Виргинские острова являются богатейшим районом Карибского бассейна [2].

В настоящее время в состав Виргинских островов входят следующие основные острова - Тортола, Верджин-Горда, Анегада, Джост Ван Дайк.
На Виргинских островах принята Конституция 2007 года (The Virgin Islands Constitution Order 2007) [3]. Также применяются нормы международного права, документы, регламентирующие статус и деятельность различных международных финансовых организаций, в работе которых участвуют публичные органы власти островов, акты, принимаемые Губернатором, местными властями.

Конституция включает преамбулу, 119 статей, варианты клятв верности и повиновения, указывает на отмененные акты конституционного характера.

До Конституции 2007 года на Виргинских островах действовал Приказ о Виргинских островах 1967 года (The Virgin Islands (Emergency Powers) Order 1967), а затем Приказ о Виргинских островах 1976 года (The Virgin Islands (Constitution) Order 1976 года) [3].

Современная Конституция впервые в истории конституционного развития Виргинских островов содержит главу о фундаментальных правах и свободах человека, а также о гарантиях их соблюдения. Содержание и виды прав и свободы основаны на Европейской конвенции о защите прав человека и основных свобод 1950 года (защита права на жизнь, защита от бесчеловечного обращения, рабства и принудительного труда, защита права на личную свободу, всеобщее избирательное право и т.д.).

Также новеллами Конституции являются нормы, регламентирующие статусы Комиссара по жалобам, Совета Национальной Безопасности, как органа подведомственного Директору службы публичного обвинения. В состав Кабинета в статусе ex officio впервые включен Генеральный прокурор, Легислатура состоит из законодательного (представительного) органа власти - Палаты Собрания и Королевы Великобритании.

2. Политико-территориальная организация Великобритании и заморских территорий (на примере Виргинских островов)

2.1. Политико-территориальная организация Великобритании и заморских территорий: проблемы конституционного нормирования и способы их решения 
В Белой Книге заморских территорий Великобритании 2012 года отношения со всеми заморскими территориями называются партнерством [4, p.7,8,9,19].

Стержнем организации и осуществления политико-территориальных отношений между Великобританией и территориями является сохранение единого подхода, в соответствии с которым полномочия избранных правительств территорий в максимально возможной степени будут соответствовать позиции Королевства о суверенитете [4, p.7,8,9,19].

Премьер-министр Великобритании Д. Кэмерон указывает, что отношения между заморскими территориями и Великобританией предусматривают баланс преимуществ и ответственности, который должна уважать каждая сторона. Правительство Великобритании желает видеть территории процветающими в партнерстве с сильной и стабильной местной экономикой [4, p.5].

Бывший министр иностранных дел Великобритании В. Хейг отмечает, что правительство наблюдает за расцветом сообществ, сохранением британской идентичности и созданием новых возможностей для подрастающего и будущих поколений, защитой природной среды и созданием самых высоких международных стандартов в этих сферах $[4, \mathrm{p} .6]$.

Взаимодействие Великобритании и заморских территории осуществляется по следующим направлениям: создание диверсифицированных и устойчивых экономик, сокращение дефицита сектора публичных услуг, эффективное регулирование финансовой деятельности, защита биоразнообразия и природных ресурсов, поддержка частного сектора, профессиональных объединений и гражданского общества.

Важным элементом организации взаимодействия Великобритании и заморских территорий является сотрудничество по вопросам безопасности. Так, в Белой книге указывается, что Соединенное Королевство стремится обеспечить защиту территорий и народов от внешних угроз, а также права на самоопределение; оказывает помощь территориям по вопросам защиты от международного терроризма, организованной преступности и стихийных бедствий; территории предоставляют Соединенному Королевству и союзникам возможность стратегического размещения баз с поддержкой широкого спектра операций по обеспечению безопасности $[4, \mathrm{p} .8]$.

Правительство Великобритании обеспечивает поддержку территорий в таких ключевых сферах общественной жизни, как образование, здравоохранение, занятость, культура и спорт.

В области организации и осуществления управления территориями Великобритания имеет определенный объем обязательств и ответственности. В Белой Книге указывается, что правительство Великобритании ответственно перед населением территорий и Соединенного Королевства по вопросам обеспечения надлежащего управления территориями. Правительство признает чувствительность данной области деятельности, но убеждено, что жители территорий имеют право ожидать получения таких же высоких стандартов управления как в Великобритании, включая область прав человека, верховенства закона и интеграции в рамках общественной жизни [4, p.9].

При этом между заморскими территориями имеются существенные различия, что обусловливает содержательную специфику «партнерства».

Так, применительно к Виргинским островам «партнерство» характеризуется взаимодействием, обусловленным широким спектром интересов в рамках оказываемых на островах финансовых и туристических услуг. В Белой Книге указано, что роль Виргинских островов наряду с Бермудскими и Каймановыми островами на международных финансовых рынках, а также усилия правительств этих территорий по обеспечению соответствия данного сектора международным стандартам, признаны международным сообществом. Сектор финансовых услуг быстро растет в течение последнего десятилетия и в настоящее время образует около 60\% всех доходов правительства Виргинских островов. Правительство Виргинских островов специализируются на регистрации международных коммерческих компаний, что составляет около 45\% мирового рынка. К концу 2011 года было зарегистрировано свыше 450 тыс. компаний. Туризм дает $30 \%$ ВВП [4, p.123].

В свою очередь, Острова Питкэрн являются заморской территорией Великобритании в Тихом океане, где на площади 56 кв.м. постоянно проживает 48 человек. Общая численность населения составляет около 56 человек за счет приглашаемых из Новой Зеландии школьного учителя, врача, полицейского, социального работника. Снабжение осуществляется морским транспортом из Новой Зеландии ежеквартально. Большинство населения заморской территории Питкэрн занимается изготовлением поделок, торговлей ими с проходящими судами, а также участвует в деятельности, осуществляемой органами власти острова [4, p.70].

Сравнение объективных характеристик приведенных в качестве примеров заморских территорий свидетельствует о том, что «партнерство» ассиметрично. В зависимости от конкретных индивидуализирующих признаков заморских территорий, в текущем режиме определяется формат их взаимодействия с Великобританией, сущностно-содержательные параметры которого, с нашей точки зрения, 
также должны быть отражены на конституционном уровне в виде соответствующих принципов.

2.2. Конституционный формат политикотерриториального отношений Великобритании и Виргинских островов: проблемы и пути их решения

В Конституции Виргинских островов политико-территориальные отношения с Великобританией регламентируются фрагментарно.

В преамбуле конституции указано, что население Виргинских островов выразило желание к самоуправлению и осуществлению высочайшего уровня контроля в отношении дел своей страны, а Соединенное Королевство выразило желание на вступление в современное партнерство с Виргинскими островами на основе взаимного уважения и самоопределения.

В последующих положениях Конституции Виргинских островов порядок и формы взаимодействия островов и Великобритании, как субъектов политико-правового пространства, системно не определены. Конституционный акт регламентирует лишь отдельные аспекты участия британского монарха и правительства по вопросам назначения Губернатора, реализации им полномочий, фиксирует неограниченность прав британского монарха в сфере принятия актов для мира, порядка и добронамеренного управления и т.д.

В части нормирования принципов партнерства следует отметить, что в одних случаях в конституциях заморских территорий эти принципы отражаются, в других - нет. При этом одни и те же принципы могут быть продублированы в конституциях разных заморских территорий.

Так, в соответствии со статьей 1 Конституции Питкэрна взаимоотношения с Великобританией основываются на следующих принципах: добросовестность, верховенство закона, надлежащее управление, эффективное финансовое управление, беспристрастное отправление правосудия, беспристрастность государственной службы, обеспечение общественного порядка, соблюдение принятых международных обязательств Соединенного Королевства и Питкэрна, обеспечение международного мира и безопасности, права на индивидуальную и коллективную самозащиту [5].

Идентичные формулировки используются в Конституции островов Святой Елены, Вознесения, Тристан-да-Кунья [6].

В конституциях Бермудских островов [7], островов Ангилья, Теркс и Кайкос [8] нормы, регулирующие политико-территориальную организацию и порядок регуляции взаимоотношений с Великобританией, не закреплены.

При отсутствии положений, регламентирующих принципы организации и осуществления по- литико-территориального взаимодействия Королевства с заморскими территориями, закономерно актуализируются проблемы разграничения полномочий и предметов ведения между их публичными органами власти.

Как указано выше, стержнем партнерских отношений Великобритании с заморскими территориями является понятие «суверенитет Королевства». Между тем данный термин не имеет юридических точных критериев квалификации, в связи с чем, возрастают риски аргументации принятия тех или иных решений властями британской Короны со ссылкой на «суверенитет» вразрез с интересами заморской территории. Данная проблематика особенно актуальна в свете широко применяемых в конституциях заморских территориях подходов по принятию правовых актов представителями Великобритании для «мира, порядка и добронамеренного управления».

Так, на основе абстрактного содержания формулировок вышеназванных целей осуществления законотворческой деятельности может быть допущена подмена исполнения функций местных органов власти. Например, в 2003 году Губернатор острова Питкэрн принял «шквал ордонансов, резолюций, приказов и правил, некоторые из которых вступили в действие без согласования с Советом (представительный орган). Такое управление привело к обострению отношений. Население Питкэрна считает, что их культура и удаленное географическое положение при законодательном регулировании требует более внимательного отношения» [9, р.33].

Существует и обратная ситуация, когда принимаемые на заморских территориях правовые акты вызывают неоднозначную оценку.

Например, в законодательстве заморской территории Ангилья предусмотрен статус гражданина и жителя, определен порядок приобретения указанных статусов [10].

В этой связи обращается внимание на то, что термин «житель» нетипичен для правовой подсистемы Ангильи и имеет недостатки в части регламентации оснований его приобретения [11, p.79]. За последние двадцать лет тысячи ямайцев, британцев, американцев наводнили Ангилью. Через несколько лет они в порядке натурализации приобретают статус жителя острова. Существует мнение, что если этот процесс продолжится, то Ангилья будет заполнена толпами иностранцев [12].

В других случаях власти Великобритании, не имея адекватных инструментов контроля, лишены возможности в полной мере владеть ситуацией на заморских территориях. Так, в 2013 году общественности стало известно содержание доклада, в котором отражены факты насилия в отношении 
несовершеннолетних, насилия в семье и сексуальной эксплуатации на островах Святой Елены и Вознесения. Как отмечается в литературе, на островах Святой Елены и Вознесения установлены факты признания в качестве нормы сексуализации несовершеннолетних, а сексуальное насилие и жестокость, по заверению работников медицинских работников острова Святой Елены, являются типичными [13]. Губернатор острова Святой Елены по данному вопросу пояснил: «Мы открыты и в полной мере взаимодействуем с несколькими независимыми обозревателями. Как и в любом небольшом сообществе, мы признаем, что внешняя оценка часто является лучшим мнением для установления фактов. Обвинения, выдвинутые в средствах массовой информации Великобритании, являются серьезными, и наш долг ответить на них. Для этого в срочном порядке выдвинутые обвинения будут рассматриваться с партнерами в Великобритании» [13].

Приведенные примеры свидетельствуют о необходимости конституционного закрепления порядка разграничения компетенции между публичными органами власти с определением ответственности за исполнение задач и функций в конкретных сферах деятельности. В частности, в конституциях заморских территорий следовало бы определить перечень предметов исключительной, конкурирующей (совместной) компетенции, а остаточную компетенцию закрепить за местными властями. Принятие такого решения позволит обеспечить прозрачность, четкость, прогнозируемость конституционного нормирования порядка политико-территориального взаимодействия.

Одновременно с этим предлагается отказаться от применения термина «партнерство», так как данный термин не отражает действительную правовую природу отношений Великобритании и заморской территории. Идентифицировать Великобританию с любой из заморских территорий как партнеров в силу объективных причин невозможно.

Применительно к Виргинским островам заметим, что статус заморской территории определялся с решающим участием Великобритании, проект конституции обсуждался в Лондоне, законодательством Великобритании определено гражданство заморских территорий, Королева является главой государства и назначает Губернатора, Великобританией осуществляется контроль реализации наиболее важных политических направлений деятельности Виргинских островов. При этом на островах созданы представительные и исполнительные органы, с учетом местных особенностей принимаются правовые акты, существует собственная символика, предусмотрен статус гражданина и жителя, определены гарантии недопустимости произволь- ного вмешательства со стороны властей Великобритании в функции местных органов власти.

С учетом изложенного, предлагается рассматривать природу политико-территориальных отношений между Великобританией и Виргинскими островами как унитарные с элементами федеративных.

В этом аспекте прослеживается сходство политико-территориального устройства Великобритании и Нидерландов. Так, в состав Королевства Нидерланды входят Нидерланды и ее заморские территории - Аруба и другие Нидерландские Антильские острова. Конституции заморских территорий Нидерландов были приняты Правительством и Палатой Представителей Нидерландов, голландский Король - глава Королевства в каждой из двух «заморских территорий», вопросы внешней политики и обороны входят в компетенцию Правительства Королевства, независимость островов ограничена принципом поддержания единства Королевства, по вопросам внутреннего управления созданы аналогичные по структуре и компетенции публичные органы власти [14, с. 84-88].

Наличие общих конституционных характеристик политико-территориальной организации Королевства Нидерланды и Великобритании в контексте регуляции статуса заморских территорий свидетельствует об общих закономерностях, принципиально не исключающих применение единообразных подходов конституционной квалификации статуса данных типов государственных образований.

Вместе с тем политико-территориальная организация Британского Содружества могла бы быть совершенней при конституционной фиксации принципов и порядка разграничения компетенции публичных органов власти Великобритании и заморских территорий на основе учета реальной специфики их взаимодействия.

Как представляется, конституционное отражение объективной картины взаимоотношений Великобритании и заморской территории способствует созданию более конструктивной основы реализации государственной политики Королевства.

\footnotetext{
3. Система публичных органов власти Виргинских островов

3.1. Губернатор Виргинских островов как представитель британской Короны

В соответствии со статьей 35 Конституции на Виргинские острова Королевой Великобритании назначается Губернатор. При этом положения, устанавливающие порядок проведения предварительных консультаций с властями заморской территории по конкретным кандидатурам не закреплены, в связи с чем, возникают определенные
} 
трудности адаптации представителя британской короны к локальным условиям.

По словам бывшего Премьер-министра Виргинских островов (2007-2011) Р. О’Нила между Губернатором и управляющими всегда есть разногласия. Р. О’Нил отмечает: «Когда речь идет о назначении лица на должность Губернатора нам даже не сообщают что это за лицо, откуда он, какой его опыт деятельности, откуда известно, что кандидатура будет соответствовать сообществу. У нас есть опыт работы с Губернаторами, которые не вписывались в сообщество; к ним относились с уважением только потому, что они представители британской Короны» [15, р.1-2].

На наш взгляд, позиция Р.О’Нила заслуживает поддержки. Думается, что предварительное обсуждение с местными властями кандидатур Губернаторов целесообразно на всех заморских территориях.

В целях оказания содействия и поддержки при осуществлении полномочий Губернатора из «виргинцев» назначается заместитель Губернатора. Данное лицо замещает Губернатора в период его отсутствия, а также реализует отдельные переданные ему полномочия.

На наш взгляд, конституционное закрепление обязанности назначения на должность заместителя Губернатора-виргинца повышает уровень репрезентации интересов местного населения в деятельности британских властей, минимизирует риски концентрации власти в ведении Губернатора. Представляется обоснованным рассмотреть возможность применения данного подхода в других заморских территориях. Например, конституционно предусмотреть порядок назначения заместителя Губернатора на острова Ангилья, Бермудские острова, Администраторов на острова Вознесения, Тристан-да-Кунья из местных жителей и т.д.

Статья 21 Конституции Виргинских островов устанавливает, что Губернатор осуществляет свои функции в соответствии с рекомендациями Кабинета или Министра, действующего под руководством Кабинета. При этом статья 22 Конституции определяет, что Губернатор может не принять рекомендацию к исполнению и передать ее на повторное рассмотрение. В судебном порядке разногласия Губернатора с местными властями рассматривать запрещено.

Губернатор обязан консультироваться с Кабинетом при осуществлении функций, возложенных на него Конституцией или иными законами Виргинских островов (статья 40 Конституции). При этом определен перечень вопросов и случаев, на которых данное правило не распространяется. В частности, это ситуации, когда Губернатор действует согласно указаниям Королевы; при осуществлении дискреционных полномочий, реали- зации функций в соответствии с рекомендациями должностного лица или органа власти, кроме Кабинета; по основаниям, предусмотренным в статье 60 Конституции.

Статья 60 Конституции определяет круг вопросов, относящихся к исключительной компетенции Губернатора, за ход и результаты решения которых он несет ответственность. Это вопросы внешней политики, обороны, внутренней безопасности, администрирование судебных органов, сроки и условия прохождения публичной службы.

Вместе с тем даже при осуществлении указанных полномочий, Губернатор консультируется и информирует Премьер-министра (статьи 40, 60 Конституции). Когда Губернатор действует вопреки рекомендациям Кабинета, конституционно установлена обязанность Губернатора представить отчет о своих действиях и их причинах Министру иностранных дел Великобритании.

C предварительного одобрения Министра иностранных дел Великобритании, а также исходя из целей наилучшего обеспечения интересов Виргинских островов, и при недопущении нарушения интересов британской Короны, полномочия по вопросам внешней политики и внутренней безопасности могут быть делегированы для исполнения Премьер-министру или иным министрам.

Предусмотрен перечень вопросов внешней политики, которые Губернатор обязан делегировать Премьер-министру или другим министрам с возложением на них ответственности за их исполнение (статья 60 Конституции). Это вопросы, касающиеся Карибского Общества, Организации государств Восточно-Карибского бассейна, Ассоциации государств Карибского бассейна, Экономической комиссии ООН для Латинской Америки и Карибского бассейна, а также любых других региональных организаций или институтов Карибского бассейна. Все региональные вопросы Карибского бассейна, касающиеся Виргинских островов, взаимоотношения с Виргинскими островами США, Европейским Союзом (в части интересов Виргинских островов), туризм и все, что с ним связано, налогообложение и регулирование рынка финансовых услуг, также передаются для исполнения местному правительству.

При этом Конституция определяет ряд требований, подлежащих обязательному соблюдению при делегировании вопросов в сфере внешней политики. Так, полномочия для ведения официальных переговоров и заключения международных соглашений должны быть испрошены у Министра иностранных дел Великобритании; ни одна политическая декларация, заявление или соглашение по вопросам внешней политики не могут быть подписаны или поддержаны правительством Виргин- 
ских островов без предварительного одобрения Министра иностранных дел; официальное приглашение члена правительства или главы государства о посещении Виргинских островов не может быть направлено без предварительной консультации с Губернатором; расходы на осуществление направлений деятельности по данному блоку вопросов возлагаются на правительство Виргинских островов; Премьер-министр или министр Кабинета должны представлять Губернатору полную информацию о реализации полномочий по этим направлениям деятельности.

Любые споры по делегированным полномочиям рассматриваются Министром иностранных дел, а принятые им решения считаются окончательными и подлежащими неукоснительному исполнению.

3.2. Кабинет Виргинских островов: формирование, состав, компетенция, ответственность

В соответствии со статьей 46 Конституции исполнительная власть на Виргинских островах принадлежит британскому монарху, а ее осуществление возложено на Губернатора и подчиненных должностных лиц.

В целях осуществления исполнительных полномочий, а также контроля реализуемых направлений деятельности, развития островов формируется Кабинет, который состоит из Премьер-министра, четырех министров и Генерального прокурора в статусе ех officio. Количество министров может быть увеличено при повышении численности членов Палаты Собрания. При этом, количество министров не может превышать две пятые от общего числа избранных членов Палаты Собрания (статья 47 Конституции).

Кабинет несет коллективную ответственность перед Палатой Собрания за формирование и реализацию политики на островах, кроме направлений деятельности, определенных статьей 60 Конституции, и отнесенных к предметам исключительного ведения Губернатора.

На заседаниях Кабинета, насколько это практически возможно, должен присутствовать и председательствовать Губернатор (статья 49 Конституции).

Следует отметить, что такой подход нетипичен для всех заморских территорий Великобритании. Иногда функции председательствующего лица на заседаниях правительства осуществляет глава исполнительного органа власти. Например, на Бермудских островах Премьер-министр созывает Кабинет и председательствует на его заседаниях (статья 64 Конституции).

Премьер-министр назначается Губернатором из членов политической партии, имеющих набольшее количество замещенных мандатов в Палате Собрания. При отсутствии партии большинства или непредоставлении рекомендации Губернато- ру о назначении соответствующего члена политической партии Премьер-министром, Губернатор назначает Премьер-министра из членов Палаты Собрания, пользующихся, по мнению Губернатора, наибольшей поддержкой (статья 52 Конституции). Министры назначаются Губернатором по совету Премьер-министра из членов Палаты Собрания, один из которых занимает должность заместителя Премьер-министра.

Статья 53 Конституции устанавливает, что решением большинства членов Палаты Собрания Правительству Виргинских островов может быть выражено недоверие. В этом случае Губернатор должен отправить в отставку Премьер-министра, что влечет за собой отставку Кабинета в целом.

При этом предусмотрен механизм сдерживания Палаты Собрания. Названная статья Конституции устанавливает, что перед принятием решения об отставке Кабинета, Губернатор обязан проконсультироваться с Премьер-министром и при наличии соответствующей просьбы главы правительства, представитель Короны по своему усмотрению вправе принять решение о роспуске Палаты Собрания.

В этом аспекте прослеживаются определенные отступления от классической Вестминстерской системы правления, при которой решение представительного органа о выражении недоверия правительству влечет безусловную отставку Кабинета.

Пост Премьер-министра становится также вакантным после всеобщих выборов членов Палаты Собрания и до проведения первого заседания в случае, если Палатой Собрания на указанную должность планируется назначение иного лица.

Решением Губернатора по совету Премьер-министра на министров может быть возложена ответственность за реализацию соответствующего направления деятельности правительства (статья 56 Конституции).

В текущий период министр финансов и всеобщего территориального представительства является по должности Премьер-министром, а его заместитель занимает должность министра природных ресурсов, занятости и представительства семи районов. Также в составе Кабинета работают министры, курирующие вопросы здравоохранения, социального развития, коммуникации, труда, образования, культуры. В общей сложности Кабинет состоит из 8 членов [16].

3.3. Легислатура Виргинских островов: формирование, структура, компетенция, ответственность

Согласно статье 62 Конституции Легислатура Виргинских островов состоит из Королевы Великобритании и Палаты Собрания. Основной целью 
функционирования Легислатуры определено принятие законов для мира, порядка и добронамеренного управления на Виргинских островах. При этом согласно статье 119 Конституции Королева Великобритании обладает самостоятельными неограниченными полномочиями для принятия законов в названных целях.

В состав Палаты Собрания входят Спикер, 13 избранных членов, Генеральный прокурор в статусе ex officio. Количество членов депутатского корпуса может быть увеличено при изменении численности избирательных округов (статья 63 Конституции). Кворум для принятия решений составляет 7 человек, исключая председательствующего.

Для избрания членов Палаты Собрания формируются единый избирательный округ, от которого избираются четыре члена, а также девять одномандатных избирательных округов. По истечении четырех лет с момента проведения первого заседания Палаты Собрания после всеобщих выборов Губернатор обязан распустить данный орган.

Членами Палаты Собрание могут быть лица, которые квалифицированы по признаку наличия пассивного избирательного до вступления в силу Конституции 2007 года, а также «виргинцы» («Virgin Islander»), достигшие возраста 21 года.

Статьей 65 Конституции Виргинских островов для приобретения статуса «виргинца» установлен ряд требований. В частности: 1) рождение на островах; 2) приобретение гражданства Британских заморских территорий в силу рождения, регистрации или натурализации на Виргинских островах; 3) происхождение (национальный признак) от отца или матери, родившихся на островах; 4) постоянное проживание; 5) рождение от родителей-«виргинцев»; 6) усыновление (удочерение) «виргинцем», приобретшим данный статус по рождению или в силу происхождения.

Не могут быть избраны в Палату Собрания, а также лишаются мандата лица, состоящие в коммерческих отношениях с правительством Виргинских островов в предусмотренных Конституцией случаях, объявленные банкротами в любой стране, душевнобольные, осужденные по отдельным категориям уголовных дел, в том числе связанными с выборами.

В принудительном порядке депутатские полномочия прекращаются досрочно при непосещении определенного количества заседаний Палаты Собрания, утрате избирательной правосубъектности. Кроме этого, член Палаты Собрания вправе самостоятельно подать заявление на имя Спикера об освобождении его от занимаемой должности.

Активным избирательным правом обладают «виргинцы», достигшие на дату проведения голосования возраста 18 лет, постоянно проживающие и являющиеся резидентами Виргинских островов, а также лица, имеющие право на постоянное проживание, как на британских, так и на американских Виргинских островах. Активное избирательное право также сохраняется за теми, кто был квалифицирован в качестве избирателя до вступления в силу действующей Конституции (статья 68 Конституции).

Лишены активного избирательного права душевнобольные, лица, утратившие статус избирателя в связи с признанием их виновными в совершении преступления в сфере выборов, лица, в отношении которых судом вынесен смертный приговор, или осуждены к лишению свободы на срок более 12 месяцев.

Председательствует на заседаниях Палаты Собрания Спикер, при его отсутствии - заместитель Спикера, либо иной член Палаты Собрания, не являющийся Министром Кабинета. Спикера и его заместителя избирают на первом после проведения всеобщих выборов заседании. При этом конституционно установлен запрет назначения на указанные должности членов Палаты Собранияминистров Кабинета. Дата и место проведения заседаний Палаты Собрания определяются Губернатором по совету Премьер-министра (статья 83 Конституции).

Согласно статье 70 Конституции Губернатор назначает Лидера оппозиции из членов Палаты Собрания, пользующихся наибольшей поддержкой самой крупной оппозиционной партии. При отсутствии соответствующей рекомендации или оппозиционной политической партии, Губернатор по своему усмотрению назначает Лидера оппозиции из членов Палаты Собрания, пользующихся поддержкой депутатов, оппозиционно настроенных к Правительству. Лидер оппозиции, также как и Спикер или заместитель Палаты Собрания, не вправе замещать должность министра Кабинета.

В текущий период в состав Палаты Собрания входят Спикер, пять министров, включая Премьерминистра, два младших министра (не являются членами Кабинета), Лидер оппозиции Ее Величества, член оппозиции Ее Величества, еще четыре депутата, из которых три являются заднескамеечниками [16].

Решения принимаются Палатой Собранием большинством избранных и присутствующих на заседании членов. Председательствующий участвует в голосовании при равенстве голосов.

Члены Палаты Собрания обладают правом законодательной инициативы по всем выносимым на заседания вопросам. При рассмотрении биллей, которые, по мнению председательствующего на заседании Палаты Собрания касаются вопросов налогообложения и финансов, обязательным явля- 
ется получение рекомендации Министра финансов Виргинских островов.

Предусмотрено два основных варианта вступления принятых Палатой Собрания биллей в силу. В первом случае их одобряет и подписывает Губернатор от имени Королевы Великобритании, а затем они проходят процедуру опубликования. Во втором случае Королева Великобритании выражает одобрение на принятие билля через Министра иностранных дел и Губернатора в виде прокламации, опубликованной в Бюллетене (статья 79 Конституции).

Соответственно, при поступлении Губернатору принятого Палатой Собрания проекта билля, он вправе подписать его, либо оставить для подписания Королеве Великобритании. После одобрения проекта билля Министром иностранных дел Великобритании, Губернатор вправе оставить его для подписания британскому монарху только в случаях несовместимости с обязательствами Ее Величества или Правительства Ее Величества в отношении любого государства, полномочий или международной организации, риска нанесения ущерба королевским прерогативам, противоречии Конституции Виргинских островов (статья 79 Конституции).

Любой одобренный Губернатором законом может быть отменен Королевой Великобритании через Министра иностранных дел. При этом ни один закон не может быть аннулирован до истечения срока уведомления Министром иностранных дел Великобритании о своем решении Губернатора Виргинских островов.

При необходимости обеспечения соблюдения международных обязательств Виргинских островов и отсутствия возможности у Палаты Собрания скорректировать или принять билль в той форме и в те сроки, которые указал Губернатор, представитель Короны вправе объявить такой законопроект действующим в своей редакции (статья 81 Конституции). Для реализации данного правомочия Губернатор должен первоначально предоставить декларацию Кабинету для получения рекомендаций о ее принятии. По истечении сроков направления рекомендаций (сроки определяются Губернатором самостоятельно), Губернатор вправе представить для рассмотрения данный вопрос Министру иностранных дел, и при получении от него разрешения, может принять декларацию.

Как представляется, предусмотренные Конституцией условия применения Губернатором «права вето» отражают широкие автономные начала в нормотворческой сфере деятельности публичных органов власти Виргинских островов, а сконструированный порядок согласования несовпадающей позиции Губернатора, а равно призна- ние вступившим в силу билля в собственной редакции фактически исключает возможность подмены деятельности местных органов власти.

B.H. Simamba отмечает, что в ведении Соединенного Королевства сохраняются всеобъемлющие полномочия для отмены правовых актов Палаты Собрания, применяемые крайне редко [17, р.131].

Досрочный роспуск Палаты Собрания возможен Губернатором после консультаций с Премьерминистром (статья 84 Конституции). При возникновении чрезвычайной ситуации, возникшей в период между роспуском Палаты Собрания и следующими всеобщими выборами ее членов, Губернатор вправе после консультаций с Премьер-министром созвать Палату Собрания распущенного созыва до момента проведения очередных выборов (статья 85 Конституции). После роспуска Палаты Собрания, следующие всеобщие выборы проводятся через два месяца (статья 86 Конституции).

\section{4. Иные публично-властные институты} Виргинских островов

На Виргинских островах создана судебная система, включающая магистратский суд, Верховный Суд и Апелляционный Суд Восточно-Карибского Верховного Суда. Высшей апелляционной инстанцией определен Судебный комитет Тайного Совета.

Магистратский суд является низшим звеном судебной системы Виргинских островов, на уровне которого рассматриваются незначительные гражданские иски, отношения, вытекающие из семейных правоотношений, уголовные дела, преступления, рассматриваемые в порядке суммарного производства (проводится по преступлениям небольшой тяжести).

Восточно-Карибский Верховный Суд определен в качестве высшей судебной инстанцией общей юрисдикции. Виргинские острова в Верховном Суде представлены одним судьей.

Оспаривание решение магистратского суда и Верховного Суда осуществляется в Апелляционном Суде Восточно-Карибского Верховного Суда. Окончательной апелляционной инстанцией является Судебный комитет Тайного Совета.

В целях консультирования Губернатора по вопросам внутренней безопасности на Виргинских островах формируется Совет Национальной Безопасности. В его состав входят Губернатор (председатель), Премьер-министр, другие министры, назначаемые Губернатором по совету главы правительства, Генеральный прокурор и Комиссар полиции в статусе ех officio.

Комиссар полиции обязан обеспечивать проведение регулярных заседаний Совета Национальной Безопасности по вопросам внутренней безопасности, информировать Премьер-министра по существенным вопросам, касающимся безопас- 
ности на Виргинских островах. Также указанное должностное лицо несет ответственность за исполнение полицией своих функций с представлением регулярных отчетов Губернатору.

Генеральный прокурор является главным юридическим советником Правительства Виргинских островов, назначается Комиссией судебной и правовой службы из «виргинцев» при условии наличия практического опыта работы по юридической профессии не менее 10 лет (статья 95 Конституции).

Наряду с Генеральным прокурором Конституцией предусмотрена должность Директора службы публичного обвинения. Указанное лицо уполномочено возбуждать и осуществлять уголовное преследование до разрешения вопроса судом в связи с совершением любого преступления; прекращать производство по уголовным делам до принятия судом решения; продолжать расследования по уголовным делам, возбужденным иными должностными лицами или органами.

По аналогии с другими заморскими территориями (Питкэрн, Бермудские острова, острова Ангилья), Губернатором после консультаций с Премьер-министром и Лидером оппозиции назначается Комиссар по жалобам, фактически реализующий функции местного Омбудсмана. Он неподотчетен какому-либо органу либо должностному лицу. Порядок, функции и полномочия Комиссара по жалобам определяются законом.

В целях обеспечения учета интересов Виргинских островов при формировании и проведении Великобританией государственной политики предусмотрено представительство данной заморской территории в Лондоне.

В 2002 году был открыт офис представительства Виргинских островов в целях выражения интересов населения и Правительства островов во взаимодействии с Соединенным Королевством и Европой. Основными направлениями деятельности данной структуры являются усиление взаимодействия с Правительством Ее Величества, повышение регионального и международного влияния, а также репутации Виргинских островов, продвижение инвестиций на островах, поддержка виргинцев (студентов и жителей), обеспечение дипломатического представительства в Соединенном Королевстве и Европе [18].

В свою очередь, специалисты указывают: «Учитывая тот факт, что британский Парламент может принимать законы, имеющие непосредственное отношение к Виргинским островам, правительство Виргинских островов должно иметь более широкий доступ к Парламенту Соединенного Королевства с целью обеспечения максимального представительства своих интересов» [15, р.224].
Полагаем, что в данном аспекте целесообразно учесть опыт конституционного регулирования статуса заморских территорий Нидерландов, в соответствии с которым министры, представляющие Нидерландские Антильские острова и Арубу, включены в состав Правительства. Кроме того, парламентские органы указанных заморских территорий информируют Парламент Нидерландов о своем мнении по законопроектам, касающимся всего Королевства [14, с. 84-88].

\section{4. Выводы и предложения}

Полагаем обоснованным квалифицировать вид политико-территориальных отношений между Великобританией и Виргинскими островами в качестве унитарных с элементами федеративных.

Рассматриваемая заморская территория обладает высоким уровнем автономии. Прежде всего, об этом свидетельствуют конституционно установленные объем и вид закрепленных полномочий публичных органов власти Виргинских островов, фиксация специальных условий участия Губернатора в вопросах внешней политики регионального характера, ограничительные механизмы для прямого вмешательства представителя британской короны в экономику территории.

На Виргинских островах создана министериалистская система правления, при которой решающую роль в формировании и реализации конституционного курса играет Кабинет.

Особое место в системе публичных органов власти Виргинских островов занимает Премьерминистр. От позиции указанного должностного лица зависят результаты рассмотрения вопросов об отправлении Кабинета в отставку, роспуске Палаты Собрания, с ним осуществляется согласование кадровых решений.

Конституционные полномочия Губернатора существенно ограничены, и фактически сосредоточены в сферах представительства и мониторинга соответствия принимаемых на островах решений генеральной политической линии Великобритании.

В целях минимизации рисков возникновения конфликтных ситуаций по вопросам разграничения компетенции представляется обоснованным более тщательно регламентировать компетенцию публичных органов власти Виргинских островов, а также Губернатора. В отличие от Великобритании, Конституция Виргинских островов - это единый целостный документ, обладающей высшей юридической силой, который, кроме прочего, предусматривает систему и порядок формирования (назначения) и деятельности публичных органов власти и должностных лиц. В указанных условиях объективно необходимо конкретизировать также предметы их ведения и полномочия. 
Полагаем обоснованным уточнить предусмотренные в Конституции основания и порядок согласования позиций по вопросу о роспуске Палаты Собрания Виргинских островов (статья 53 Конституции). Закрепленная в Конституции фабула о том, что перед принятием решения об отставке Кабинета Губернатор обязан проконсультироваться с Премьер-министром и при наличии соответствующей просьбы главы правительства Губернатор по своему усмотрению вправе принять решение о роспуске Палаты Собрания, могла бы быть дополнена положениями, предусматривающими обязательность участия в консультациях Спикера и Лидера оппозиции. Также в Конституции целесообразно конкретизировать содержание и порядок организации и проведения согласительных процедур, основания рассмотрения вопросов об отставке Кабинета, досрочном роспуске Палаты Собрания, критерии принятия таких решений.

В целях расширения возможностей для выражения позиций Виргинских островов на уровне Соединенного Королевства предлагается предусмотреть механизмы представительства Кабинета в Прави- тельстве Великобритании путем включения в его состав соответствующих министров от территории.

Для повышения эффективности взаимодействия по вопросам законодательной деятельности представляется обоснованным конституционно установить порядок представления Палатой Собрания в Парламент Великобритании информации о своем мнении по законопроектам, касающимся всего Королевства, а также предусмотреть направление Парламентом Великобритании проектов правовых актов, затрагивающих интересы Содружества, в адрес заморских территорий.

В целях расширения форм прямого участия населения в деятельности по управлению Виргинскими островами, а также повышения репрезентативности принимаемых властями актов, в Конституции целесообразно закрепить референдарные механизмы участия населения в рассмотрении и решении вопросов публичного характера, включая вопросы досрочного прекращения полномочий отдельных категорий должностных лиц, проведения консультаций, иных форм непосредственной демократии.

\section{Библиография:}

1. Randall Peffer. Virgin Islands. Australia. 1st edition. Lonely Planet Publications Pty Ltd. September 2001. P. 23

2. Virgin Islands, British Business Law Handbook: Strategic Information and Laws. Volume 1. International Business Publications, USA. Washington DC, USA - Virgin Islands. P. 10-11.

3. The Virgin Islands Constitution Order 2007. URL: www.bvi.org.uk/files/constitution 2007.pdf. (дата обращения 09.03.2016)

4. The Overseas Territories. Security, Success and Sustainability. June 2012. P. 7, 8, 9, 19. URL: www.offcial-documents.gov. uk. (дата обращения 22.12.2015)

5. The Pitcairn Constitution Order 2010. www.government.pn/Pitcairn Islands Constitution Order 2010.pdf. (дата обращения 09.03.2016)

6. The Constitution of St. Helena, Ascension and Tristan da Cunha. URL : www.sainthelena.gov/sh (дата обращения 09.03.2016)

7. Bermuda Constitution Order 1968. URL: www.bermudalaws.bm/Laws/Consolidated Laws/Bermuda Constitution Order 1968.pdf (дата обращения 09.03.2016)

8. The Turks and Caicos Islands Constitution Order 2011. URL: www.legislation.gov.uk/uksi/2011/1681/pdfs/ uksi_20111681_en.pdf. URL: (дата обращения 09.03.2016)

9. Pitcairn Islands. Business Las Handbook. Strategic Information and Basic Laws. International Business Publications, USA. Washington DC-USA - Pitcairn Islands. 2013. P. 33.

10. Anguilla Constitution Order 1982. URL: http://www.gov.ai/dg/documents/Anguilla\%20Constitution\%200rder\%20 1982.pdf (дата обращения 22.12.2015)

11. Anguilla. Constitutional and Electoral Reform Commission. Report. Dated 25 august 2006. P. 79.

12. Don Mitchell. Draft of New Constitution Creates Second-Class Status of “Belonger”. URL: corruptionfreeanguilla.blogspot. ru/2009/07/belonger.html (дата обращения 23.12.2015).

13. "A culture of sexual abuse of children": Shocking report claims British overseas territory of St Helena is ride with child abuse, domestic violence and sexual exploitation. URL: www.dailymail.co.uk. (дата обращения 25.12.2015)

14. Голландская правовая культура / Отв. ред. В.В. Бойцова и Л.В. Бойцова. М., Изд-во «Легат», 1998. С. 84-88.

15. Overseas Territories. Seventh Report of Session 2007-08. Volume II. Foreign Affairs Committee. House of Commons. London: The Stationery Office Limited. 2008. P. 1-2. URL: https://www.gov.uk/government/uploads/system/uploads/ attachment_data/file/238697/7473.pdf (дата обращения 10.03.2016)

16. Government of the Virgin Islands. URL: www.bvi.gov.vg/cabinet-members (дата обращения 09.03.2016)

17. How To Make Effective Legislative Proposals. British Virgin Islands Legislative Process by Bilika H. Simamba. AuthorHouse. 2013.P.131

18. Government of the British Virgin Islands. London office. www.bvi.org.uk./londonoffice/оbјесtive (дата обращения 09.03.2016)

\section{References (transliterated):}

1. Randall Peffer. Virgin Islands. Australia. 1st edition. Lonely Planet Publications Pty Ltd. September 2001. P. 23 
2. Virgin Islands, British Business Law Handbook: Strategic Information and Laws. Volume 1. International Business Publications, USA. Washington DC, USA - Virgin Islands. P. 10-11.

3. The Virgin Islands Constitution Order 2007. URL: www.bvi.org.uk/files/constitution 2007.pdf. (data obrashcheniya 09.03.2016)

4. The Overseas Territories. Security, Success and Sustainability. June 2012. P. 7, 8, 9, 19. URL: www.offcial-documents.gov. uk. (data obrashcheniya 22.12.2015)

5. The Pitcairn Constitution Order 2010. www.government.pn/Pitcairn Islands Constitution Order 2010.pdf. (data obrashcheniya 09.03.2016)

6. The Constitution of St. Helena, Ascension and Tristan da Cunha. URL : www.sainthelena.gov/sh (data obrashcheniya 09.03.2016)

7. Bermuda Constitution Order 1968. URL: www.bermudalaws.bm/Laws/Consolidated Laws/Bermuda Constitution Order 1968.pdf (data obrashcheniya 09.03.2016)

8. The Turks and Caicos Islands Constitution Order 2011. URL: www.legislation.gov.uk/uksi/2011/1681/pdfs/ uksi_20111681_en.pdf. URL: (data obrashcheniya 09.03.2016)

9. Pitcairn Islands. Business Las Handbook. Strategic Information and Basic Laws. International Business Publications, USA. Washington DC-USA - Pitcairn Islands. 2013. P. 33.

10. Anguilla Constitution Order 1982. URL: http://www.gov.ai/dg/documents/Anguilla\%20Constitution\%200rder\%20 1982.pdf (data obrashcheniya 22.12.2015)

11. Anguilla. Constitutional and Electoral Reform Commission. Report. Dated 25 august 2006. P. 79.

12. Don Mitchell. Draft of New Constitution Creates Second-Class Status of "Belonger". URL: corruptionfreeanguilla.blogspot. $\mathrm{ru} / 2009 / 07 /$ belonger.html (data obrashcheniya 23.12.2015).

13. "A culture of sexual abuse of children": Shocking report claims British overseas territory of St Helena is ride with child abuse, domestic violence and sexual exploitation. URL: www.dailymail.co.uk. (data obrashcheniya 25.12.2015)

14. Gollandskaya pravovaya kul'tura / Otv. red. V.V. Boitsova i L.V. Boitsova. M., Izd-vo «Legat», 1998. S. 84-88.

15. Overseas Territories. Seventh Report of Session 2007-08. Volume II. Foreign Affairs Committee. House of Commons. London: The Stationery Office Limited. 2008. P. 1-2. URL: https://www.gov.uk/government/uploads/system/uploads/ attachment_data/file/238697/7473.pdf (data obrashcheniya 10.03.2016)

16. Government of the Virgin Islands. URL: www.bvi.gov.vg/cabinet-members (data obrashcheniya 09.03.2016)

17. How To Make Effective Legislative Proposals. British Virgin Islands Legislative Process by Bilika H. Simamba. AuthorHouse. 2013.P.131

18. Government of the British Virgin Islands. London office. www.bvi.org.uk./londonoffice/objective (data obrashcheniya 09.03.2016) 